DOI : $10.14746 /$ ps.2019.1.18

\title{
DIMENSIONS OF SOCIAL DIVERSITY IN EUROPE
}

The question about social diversity in a multinational Europe must lead to search for multicomponent answers. They should take into account historical and cultural contexts, and especially permanent state-economic particularisms. They determine the relationship between the EU as an institution and the Member States. They affect sectoral policies and readiness to disseminate civilizational achievements to the same extent. The ability of the EU and Europeans to implement common values more effectively and raise quality standards restricts the membership of the social policy to the competences of nation states. In addition, social policy is naturally associated with the economy and socio-political order.

Responding to the statement that Europe is not only a place but also an idea, in the social sphere it is an integral part of the civilisation's achievements and, especially in its post-war period, it is also a comprehensive civilization achievement encompassing including socio-cultural areas, law, social and political thought. Born together with the process of industrialization and the development of European nation states, it gave to a number of issues socio-political or nation-state context. The European/EU dimension of social policy should be recognized as the youngest phase in its development.

A number of our social achievements is universal, others are specific to Europe or even its selected regions. If we assume the level and quality of life as a superior value, then their condition proves the presence of many paths of socio-economic development determined by the environmental conditions. You can talk about a catalogue of common features, usually defined as the value of the European social space, and - viewed from the outside - as the level of development of our civilization and prosperity.

The categories of the European social model or the social dimension of Europe have been derived from the nation-state social policy in recent years. Along the economic order and the "welfare regime" connected with it, the level of market interference of the state and its socio-political tasks change. Therefore, and also as a result of the internal development of the EU, social and political competences of EU institutions are evolving (Stuchlik, 2008: 3-4).

From the perspective of the recent decades, characterized by a change in the balance of power between the spheres of society - the economy - the state, the question about the state, relationship and responsibility of the European policy versus national social policies is fully justified. The understanding of the importance of social issues in external relations by the European social policy makers is equally important. Global responsibility requires understanding and comprehensive binding of a number of aspects and contexts in relations with other countries, international enterprises. Long- 
term goals of sustainable development, after all, refer apply equally to the social, ecological, economic and humanitarian spheres, to democratic and political leadership (Braunsdorf, 2016: 2-3).

The literature on the subject continually typifies social policy models based on the nineteenth-century division of the political scene, the scope of redistributive and protective functions of the state. Many of these signs can be found in every country, and at the same time they are a factor in the differentiation of European models and societies. At the same time, it is worth pointing out that a number of features - due to the erosion of the structure and evolution of the family functioning model, changes in the labour market or global challenges - make us look more reflective at national social policies. Today, the effectiveness of public policies, competitive society and economy, ethnic and cultural inclusion are on the rise. Progress and the social model do not keep pace with the rapid development of economy and technology, which weakens the social dimension of the EU. Simultanously,some activities of the EU institutions are in conflict with the spirit of the treaties, violating the principle of subsidiarity in the sphere of social policy.

The most important current differences in the European social area are as follows:

- the multiplicity of different models of national social policies (Scandinavian, Anglo-American, Mediterranean, Eastern European, continental) and the heterogeneity of understanding what the European Social Area is;

- regional differentiation of levels/standards of living, there are far more than the social policy models. This state allows to distinguish the regions of Europe: North (Nord), North-West (Nord-West), North-East (Nord-East), West European (WestEurope), Southern Europe (South-Europe), South-East Europe ( South-East), Central Europe (East-Europe);

- different and "dependent" paths of development in the economic and social sphere;

- lack of unanimity in public opinion regarding social issues and how to resolve them; the lack of unanimity of public opinion on social issues and the way in which they are dealt with;

- a catalogue of questions related to the EU social policy: whether to limit it to minimum standards, including legal ones; whether to manage through structural funds; what to focus on - social equalization, subsidiarity, solidarism; to function with or without a social union; how to deal with the Member States, ie whether to force them on pro-development national social policy or only flexibly manage and react.

Social order in Europe is a key element of our identity, liberal democracy with a whole catalogue of economic, social and environmental laws. Solidarism, egalitarianism and universalism suggest a collegial approach both in the dimension of the national and European community - though to a much lesser extent. The community of values refers to the cultural heritage and the acquis. The European social model was built by states and national economies. For a number of decades this construction was accompanied by competition rivalry and imitation between countries or even bottomup pressure of social movements and trade unions. At the moment, we are simultaneously experiencing top-down pressure, eg through the open Method of Coordination or the implementation of EU strategies. Their goal is to develop and secure the 
achieved gains in the broader European and EU dimension (Alber, 2010: 103; Witte: 1; Jepsen, Serrano-Pascual: 232). The European social model from today's perspective is a conglomeration of heterogeneous solutions system and strongly differentiated social standards.It aspires to set ambitious goals within various social projects. They are to initiate modernization changes and contribute to (greater?) cohesion in horizontal and vertical, EU and national dimensions (Aust, Leitner, Lessenich: 284; Hermann, 2009: 77-78; Pfetsch: 72; Hermann, Mahnkopf, 2010: 4-5).

Meanwhile, equality and solidarism are particularly distinguished by Scandinavian social-democratic solutions, concentrated in the framework of relatively few and homogeneous societies to reduce disparities, ensuring accessibility and universality of participation in socio-social life. The historical experience, and hence the citizenship "and not the previous contribution" to the system and the supplying technique in the relationship between institutionalized and nationalized social policy and citizens, were of significant importance. The historical experience, and hence the citizenship "and not the previous contribution" to the system and the supplying technique in the relationship between institutionalized and nationalized social policy and citizens, were of significant importance. The wide and high standard range of social protection enforces full employment and very high fiscal solidarism. It is worth noting the cooperative thinking of the labour market participants, hence the focus on consensus and job security (eg as part of flexicurity).

The reality of joining forces: the nation, the state and the religious and cultural community helps to achieve the Danish hygge. The structure of the labour market is not without significance. The strongly developed public sector proves to be a very helpful instrument for promoting women's employment, leveling the disproportion even out the disparities between them and men, encouraging husbands / fathers of young children to enter into care and educational roles.

\section{Employment rates in the public sector (in 2016)}

Table 1

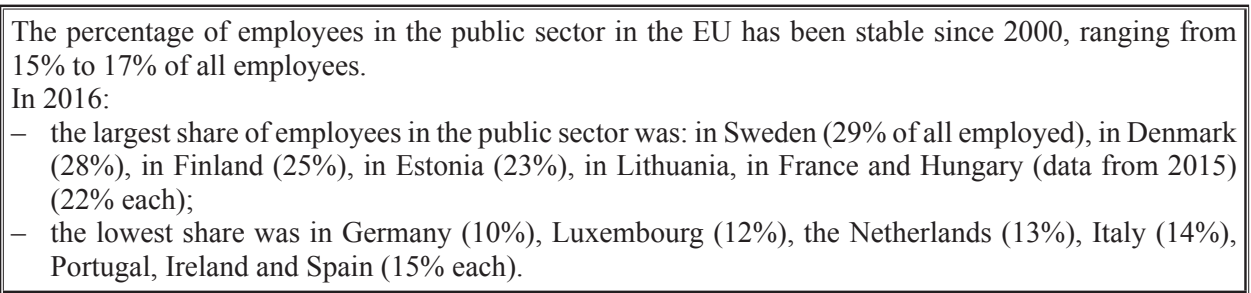

Source: Zatrudnienie w sektorze publicznym pozostaje na niemal stałym poziomie, https://stat.gov.pl/gospodarkaeuropejska/bloc-4d.html.

The liberal model of homo oeconomicus values the market as a place for satisfying needs and ensuring social security. Justice, which sanctions inequality and stratifies society, should limit the corrective intervention of the state. Justice understood in this way does not stigmatize or, by definition, does not introduce citizens to an uncommon poverty. On the contrary, the countries that promote this model of economy belong to the richest in the EU, and the state is not limited only to the role of night watchman, 
it is active in the sphere of social welfare. Individual and collective level of prosperity is achieved by high activity of citizens on the labour market and liberalized and pluralistic solutions of individual and collective labour law. Bearing in mind the progressing secularization of the Rhineland countries, to a lesser extent in the influence of religion, and more strongly in the impact of culture and society, one can find out their structure-forming function. Therefore, in this region of Europe, social solidarism refers especially to the national, local, and vocational-layer community. Social structures are opening up much slower, and social integration is not always successful (Parallelgesellschaft, Scheitern an der Integration). Practically, the universality of employment and the compulsory employment insurance guarantee the income and social security. The patriarchal family relations that were once referred to as a feature of the system lost its importance because of the popularity of alternative forms of lifeto a traditional family - for adults. The concept of the main breadwinner family wage (husband/father) is nowadays impossible to maintain without state subsidies. In the original formula, it has been preserved in higher income groups. Today, Germany can be viewed as a liberal state and a very effective economy in the field of employment promotion and ensuring a high status of citizens' lives. However, extensive labour law and active trade unions do not adequately protect against precariousness of work, the diffusion of flexible forms of employment,poverty and social exclusion. Deviation from the Soziale Marktwirtschaft took place parallel to the saturation of public space in West Germany with contemporary social issues.

A particular multiplication of social issues is noticeable in southern European countries. They "spoil" the social statistics of the old European Union. Having achieved a lower level of development and struggling with the effects of the financial crisis, they offer a basic range of services and the needs satisfaction. Processes such as: the crisis of the family institution and the birth crisis, progressive secularization undermine the protective functions of southern familiarism. This is confirmed, for example, by the recent migration of young people to the wealthier regions of Europe. Stable democracies did not keep the socio-economic stratification there, and the implemented liberal reforms of economic restructuring were to be associated with burdens resulting from servicing the senior and health policies and the labour market. Central and Eastern Europe remains heterogeneous in terms of its pathway and level of social development. Here, the size of poverty and social exclusion are significantly higher in the South East subregion than in the East Europe: in 2016, the risk of poverty/social exclusion in the Czech Republic was around 13\%, and about $40 \%$ in Bulgaria, with the EU average at 24\% (Ubóstwo, 2015: 55).Despite including these subregions in the same social policy model, ie the hybrid of collectivism, corporatism, conservatism, liberalism, post-communist social democratism, these countries differ significantly in the level of prosperity and social inclusion, the advancement of reforms, operation efficiency and transparency of the state. After all, not all countries in the region are accused of unsuccessful integration with EU structures!

The withdrawal of the state from the implementation of many social functions generated their privatization. The consumption of goods, mostly privately funded, considered to be socially important, permanently pushed us into increasing indebtedness. 
Public social spending (as a percentage of GDP, 2018)

France $-31,2$; Belgium - 28,9; Finland - 28,7; Denmark - 28; Italy - 27,9; Austria - 26,6; Sweden - 26,1; Germany - 25,1; Norway - 25; Spain - 23,7; Greece - 23,5; Portugal - 22,6; Luxembourg - 22,4; Slovenia - 21,2; Poland - 21,1; Hungary - 19,4; Czech Republic - 18,7; Estonia - 18,4; Slovak Republic - 17; Netherlands - 16,7; Latvia - 16,2; Ireland - 14,4.

OECD - 20,1; USA - 18,7; New Zealand - 18,9; Switzerland - 16.

Source: OECD (2019), Social Expenditure Database, www.oecd.org/social/expenditure.html

In Poland, mortgage loans related to the purchase of real estate are mostly responsible for the household debt spiral at the moment. In the previous period, household budgets were additionally burdened by consumer loans for current financing of families, to cover the costs of health services or leisure activities (Szewior, 2016: 258-264, 284-290; Finkenstädt, 2017: 19-65). In Poland, due to economic reasons, the model of two breadwinners, multi-tasking and overtime work became popular. It helped to reduce financial barriers to access to social services funded privatly and to raise the level of satisfaction of needs along with the standard of living of citizens. The weakness of the region for many years has been the poorer indicators of professional activity of women, shorter life expectancy of the population, wages differing from the EU average values and less civilized working conditions.

The European social model after 2008 faced a number of financial and conceptual challenges (Supiot, 2013: 19). The disproportions between the social and economic spheres, the national and global dimensions resulted in what in social policy is referred to as asymmetry. It also has its own EU dimension, because the progressive integration of EU internal markets was not accompanied by a similar process in social policy. The economic and financial changes were used to put pressure on social reforms towards liberalization and marketization as well as coordination of EU-oriented social development. The EU has stepped in with social reforms on the grounds of national competence, breaking the established division of tasks and responsibilities (Piepper, 2018: 2-7). Hence the reductions of investment outlays imposed in the public, employee and social spheres (Hermann, 2013: 5-12; Hermann, Hinrichs, Brosig, 2012: 6-45), which particularly experienced the countries of the South affected by the financial crisis (Engler, Mathals Klein, 2017: 127-133). The policy pursued for many years has consolidated social and regional disproportions as well as social acceptance of them. The crisis triggered migration processes within the EU, caused high unemployment, poverty, and dwindling social transfers (Szewior, 2015: 161-193). Social expenditure (globally counted) was reduced despite the growing number of people in need. Thus, it can be considered that this reduction in expenditure is responsible for the increase in inequality (Dauderstäd, Keltek, 2016: 3-4). Polarization between the Eastern and Western regions of Europe is seen as an initiative (from 2016) of limiting social benefits in the internal market. Linking the access to public resources with employment is intended to protect the market against welfare tourism from East European and the budgets of richer Western European countries.

In the context of the above considerations, the European Pillar of Social Rights can be considered, referring to the minimum standards of labour and social protection 
law, for convergent activities, even though they were not,in their essence, new in the development of European social legislation. In addition, their implementation will be a major fiscal burden for poorer countries. Paradoxically, this does not have to improve their competitiveness in the EU internal market. Western countries, limiting the level of liberalization of the internal market, shift competitiveness from the level of employment conditions and social protection to pro-innovative - related to intellectual capital and advanced know-how. Thus, they can promote themselves first of all at the expense of the eastern region of the EU, for which the competitive costs of labour and production were important.

Table 3

\section{Budget surpluses of EU countries (in 2018)}

-14 countries recorded budget surpluses, Luxembourg (+2.4\%) had the highest relation to GDP, fol-
lowed by Bulgaria and Malta (both by $+2.0 \%)$, Germany $(+1.7 \%)$, the Netherlands $(+1.5 \%)$, Greece
$(+1.1 \%)$, the Czech Republic and Sweden (both $+0.9 \%)$, Lithuania and Slovenia $(+0.7 \%$ each),
Denmark $(+0.5 \%)$, Croatia $(+0.2 \%)$ and Austria $(+0.1 \%)$, Ireland $(0.01 \%) ;$
- Government expenditure in the euro area accounted for $46.8 \%$ of GDP, government revenue $46.3 \%$,
in the EU $28,45.6 \%$ and $45 \%$ respectively.

Source: Mapa dlugów, deficytów i nadwyżek w UE, 2019.

The situation is not improved by the presence of different ways of developing countries and European regions, as well as a vision of their continuation. In 2017, the European Commission gave this expression to the scenarios of the future. From a social perspective, they confirmed its weakness in relation to the real impact on social change (European Commission - Communication, 2017). Among a lot of challenges, the pathway of development that the EU and its individual countries will follow is a core variable. There are many of them, and they seem to be possible today. Social politics should worry about the fact that social issues have not been adequately addressed in a series of visions. The first scenario described as Continuity its starting point see in the New Beginning for Europe in 2014, whereby the solution to the updated problems was associated with a healthy economy and public finances. Because the second scenario contains weakness in the form of selective and bilateral management of some areas, for social issues it may mean the end of unified standards and social solidarity covering only its own national group. This model of proceeding also provides the third scenario - those who want more, do more, because it opens the field for EU members to act. The cooperation of "those willing to do so" can have different dimensions and negative side effects. Countries can agree on new standards, obligations and preferential treatment. And that can mean the selectivity of solutions that have a negative impact on the socio-economic sphere. The fourth scenario may have similar effects. Do less but more effectively. The EU, focusing on selected, hard policy areas, transfers the initiative to the Member States in the spheres of sectoral policy development (health, employment, social ) and thus opens the field of differentiation and not standardization of standards. In the next fifth scenario, Doing together much more also lacked a direct reference to social issues. Therefore, it can be assumed that they will be solved through consolidating internal markets, better cohesion, improved security, and better coordination (White Paper, 2017: 8, 15-17, 20-26). 
In turn, The scenario of the development of Europe to 2025 by Jean Juncker, referring to civilization values, at the same time gives them a social and social dimension. He sees equality and inclusiveness through the prism of territorial and intergroup cohesion. He talks about their dimensions: employee, consumer and civic. This was confirmed in Göteborg, and then it was listed in the European Social Rights Pillars (European Commission - speech, 2017: 2-5). ESRP has been constructed on the principles of equality, justice and protection, with the background of the labour market, contribution and participation in social development, the convergence of national economies and the EU society (Schlussbericht, 2017: 1-4). Recall in the Social Rights Pillars for equality and justice should be particularly heard in the EU Member States. Contrary to popular opinion, responsibility for falling income and property inequality is falling on the state. For this reason, national socio-economic policies remain the basic instrument of redistribution and social stratification. The acceleration of the pace of income differentiation has been noticed since the 1980s, which is supposed to prove the end of the post-war "equality order." The regions of the world are distinguished only by the level of inequality, the degree of stability, the rate of increase in disproportions, the process of socio-economic stratification and the role of political institutions. Matchmaking shows their weakness in maintenance of democratic control and supervision over the economy, as well as the lack of resistance to external pressure of deregulation and market opening (Bericht, 2018: 5).

The image of the wealth diversification of societies is strongly inscribed in the political context and national conditions (Russia, China, India). In addition, where there is no tradition of equality-oriented society (Middle East, Sub-Saharan Africa), there the disproportions of property are of the lasting nature. The escalation of stratification is fostered by the spirit of deregulation and the opening of markets. They help primarily the richest and narrow (broad) middle class. In continental Europe, another group of factors lies on the side that generates inequality. Education and the tax system are awarded to people with a better diploma and the higher earners. Inevitably, income inequalities between women and men have flattened but remain very pronounced in the group of the highest earners. Another category of factors comes down to the unequal distribution of capital and the transfer of huge amounts from the public sphere to private hands. The Report quoted here diagnoses this paradox involving the simultaneous strong growth of national assets and the zeroing / negative value of public funds. Therefore, the countries are getting rich with the wealth of their inhabitants, but the governments of countries are becoming poorer. This state of public resources strongly limits the space for action in the social and redistributive sphere, and the financial crisis of 2008 even more strongly narrowed the activity of public authority in this area (Bericht zur Weltweiten..., 2018: 6-15).

Today's bad situation is viewed as a result of extensive privatization and increase of income inequalities within nation states. The social crisis in Europe, which has been lasting for years, has kept inequalities both between and within countries. Cohesion did not proceed as expected, even if weaker countries develop at an average faster than the EU average. Particularly stronger players benefit from weak growth, and the EU's strict fiscal policy has not helped to meet the expectations of socially weak countries (eg Mediterranean countries). Likewise, the relations between the social layers were similar. 
The data compilation for 2013-2014 showed that the richer had higher incomes and they were also losing less. Despite the stronger increase in income in Central and Eastern Europe, the disproportions in the continental dimension did not diminish, because the income in the poorest European quintile did not grow faster than the income in the richest. In addition, the countries of our region have economically weaker income groups, and the richest EU countries were basically the national quintals of the wealthiest states. The picture of Europe then resulted mainly from what was happening in the middle of the income table, and this field was taken over by the countries of the South. ${ }^{1}$

After the enlargement of the European Union in 2004, the challenge in the social sphere was to align the living standards between the new Member States and the rest of the continent. For objective reasons, the southern countries closer to us have been made the reference point, but despite this we remain far beyond the EU social standard. The highest levels of satisfaction can be found in the northern (Nord) and north-western (NordWest) countries. In the south the picture was heterogeneous, in Central and Eastern Europe "diversity and low level." The greatest extremes in the assessment of living standards are revealed between Nord-West and Nord and South-East. The situation of the labour market and the financial situation of households was similar (Scheuer, 2018: 433-435).

Inequalities get some degree of social acceptance. EU citizens favour socioeconomic inequalities at the expense of representatives of other nation-states (Gerhards, Lengfeld, 2010: 66-67; Gerhards, Lengfeld, 2013: 7-20.), which in fact strengthens the limits of community solving of social problems, in particular guaranteeing similar standards of meeting needs (Platzer, 2011: 109). Meanwhile, the research conducted by TNS-Emnid confirmed the awareness of EU countries citizens regarding the upcoming challenges and the need for social reforms. The EU institutions played an essential role in it to guarantee through the pressure on reforms the functionality of the national social systems, and also - through the relevant regulations - minimum social security standards.

Table 4

\section{Indebtedness of European countries (in 2018)}

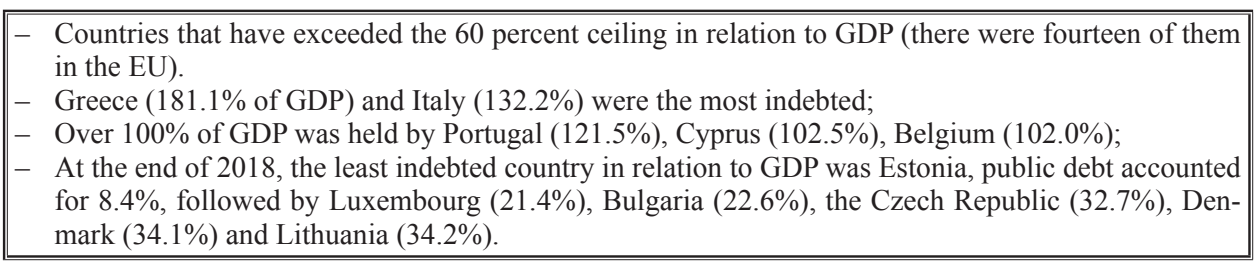

Source: Mapa dlugów, deficytów i nadwyżek w UE.

The view of the need to set minimum social standards has been strongly emphasized in statistical France and the least in Germany. The Finns and the British

1 The comparison of European and national quintiles made it possible to determine that the poorest European quintiles were mainly national quintiles from Eastern European countries (and almost all from Romania). The richest EU-quintiles were in principle only the highest national quintals of the richest countries. Some countries had the quintals of both the richest and the poorest groups (Spain, Italy), which confirms a large spread. The situation varies depending on whether the statement is carried out in euro or in KKS. M. Dauderstäd und Cem Keltek, 2016, pp. 1-3. 
most strongly rejected such a solution, in contrast to Central and Eastern Europe. It was quite clearly expected from the EU to put pressure on the member states to implement the necessary reforms of their social systems. It was not about unifying social solutions with the help of the EU, but that it would put pressure on the implementation of specific reforms. In this case, the EU should be a catalyst for regularly necessary reforms, not a guarantee of specific solutions that would look identical in all Member States. The greatest support ("definitely yes") was obtained in Poland $(47 \%)$, and in general quite clearly also in Germany and Finland. The lack of financial solidarity has revealed the answer to the next question, namely whether the EU should guarantee financial transfers from rich to poor countries. The structure of the response indicated the dependence that when citizens came from net payers, skepticism was more visible than in the recipient countries. Also, the dilemma and expectations of citizens of a balance between the level of fiscal burdens and the quality of life were dealt with differently. In a situation when taxes and social donations prove to be insufficient to maintain the current standard of living, whether to maintain the level of benefits while increasing the fiscal burden of citizens or to stabilize costs by limiting the scope of social benefits. In poorer countries, the benefits were reduced unlike the increase in taxes and tributes (Zukunft: 1-10).

A social, sustainable development understood as maintaining and raising the chances of the individual in order to ensure a high level of social inclusion remains a postulate (Nachhaltiges, 2016: 1-10). The condition is an open society in the socioeconomic dimension, with available resources and permanent ability to function effectively (financial efficiency and ability to reform). Therefore, it is expected that:

- the state's education policy supported a qualitatively high, inclusive and effective system of education and skills development;

- social-political activities raised social inclusion and effectively limited social exclusion and polarization;

- health policy permanently secured the quality and costs of the health system;

- activities dedicated to the family made it possible to reconcile the professional and family spheres;

- the policy towards the elderly people helped to avoid poverty, to be fair and financially stable;

- political action ensured the integration of immigrants;

- political activities created safe living conditions by combating crime and other security risks;

- political actions allowed to combat global social inequalities through supporting structures of world trade fair and equitable share in the developing countries.

Assessment of policy implementation in the social dimension

Norway - 7.89; Denmark - 7.67; Finland - 7.55; Sweden - 7.54; Luxembourg - 7.32; Switzerland - 7.08; Germany - 6.74; Estonia - 6.68; Slovenia - 6.32; Czech Republic - 6.20; Lithuania - 6.18; Poland - 5.94; Slovakia - 5.27; Croatia - 5.19; Latvia - 4.93; Greece - 4.81; Hungary - 4.68; Romania -4.46; Bulgaria - 4.43. 
The pluralism of institutional solutions of social policy will also refer in the future to the diversity of the level and scope of social protection (Ribhegge, 2011: 283 in). This is all the more important because the EU countries compete with each other on the citizens' living standards and institutional solutions in sectoral policies (housing, education, family assistance). The social policy will not be helped by the selective orientation towards improving the efficiency of the labour market, as it is at the expense of already obtained social security (individual and collective employee rights). The employment status or elimination of disparities between women and men as well as the scope of support granted to young people remain significant. Meanwhile, the share of young people inactive and not participating in education (NEET type) between 20082016 remained at a high and relatively stable level: $2008 \mathrm{EU}-14 \%$, Poland - 12.5\%; 2016 EU - 15.2\%, Poland - 14.1\% (Ubóstwo w Polsce w latach 2015 ..., 2017: 76).

Diversification of the position of employees on the labor market (in 2014, in 2017)

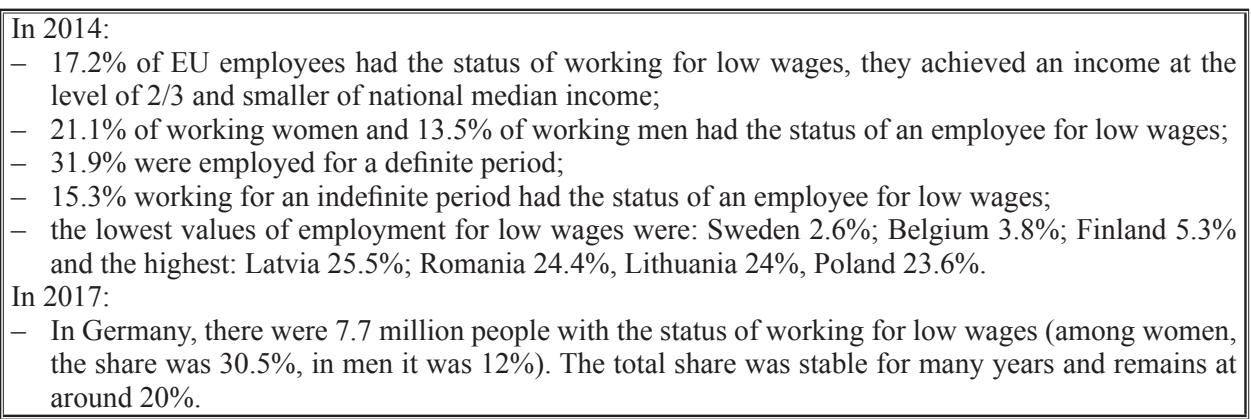

Source: Eurostat. Pressemitteilung 246..., 2016: 1-2; Statistisches Jahrbuch Deutschland und Internationales 2018, wissen.nutzen, Statistisches Bundesamt (Destatis), p. 362, https://www.destatis.de/DE/Themen/Querschnitt/Jahrbuch/statistisches-jahrbuch-2018-dl.pdf?_ blob= publicationFile\&v=5.

This is an additional point showing the gap between the EU legal and regulatory competences and the financial and redistributive powers of the Member States (Eigmüller, 2012: 263-287; Becker, 2012: 86-92). As Righegge points out, there is the existence of heterogeneous national solutions and a distinctive order in the normative sphere of the EU, as well as mismatches and subordination to economic development of socio-social changes (Dufresne, 2013: 139). Defenders of national social policies emphasize that the EU in the social sphere should be based on real competences and on financial and economic efficiency - its expenditure accounts for only $0.3 \%$ of the costs incured by the Member States. In addition, the communitarisation of social systems would lead to "irreversible transfer mechanisms and would violate the national: responsibility and sovereignty" (Piepper, 2018: 6).

Maintaining the current standard of living and social protection of citizens with increasing economic competition has become an increasingly difficult challenge for European countries. Previously, the policy of balancing public finances meant social cuts, and today in some countries social investments lead to financial imbalances and short-term consumption of good economic conditions. In relation to the outside world, Europe is today a hostage of its own history, economic success and a high standard 
of living. In the EU, social effects generate imbalances in production factors in the form of an advantage of moveable capital over less moveable human work. Initiatives undertaken in the spirit of flexicurity or more radical solutions as opening up to migrant workers is also a double-edged sword - wage pressure, socio-cultural security. It weakens the collective dimension of solidarity and social protection of homogeneous societies, enhancing the evolution of European social policy from social guarantees to activation and privatization. After the creation of eurozone, the disproportions between countries contributed to shaping the center's layout - the periphery.

The category of justice, especially social equality, was not and will not be visible through the prism of quality of life in the coming decades. Expressed, for example, by the length of life and the state of health, showed inter-gender differences, which, although they gradually disappear within one country, but not necessarily between countries or regions of Europe. The countries of Central and Eastern Europe (Datenreport, 2018: 416) were significantly different from the EU average and the best states, reasons for our position are found in four factors:

- in a worse standard of life;

- in a worse medical supply;

- in more difficult working conditions and

- in other, i.e. poorer eating habits.

Public policies and investments in human resources can help improve the indicators relating to various areas of social policy. When analyzing the level of professional activity, in many countries the attention is paid to the positive effect of multisectoral impact based on supporting education oriented at sustainable development of competences and integration with the labour market. Policy makers in the countries of Central and Eastern Europe have been convinced of the need to promote families through simultaneous stimulation of fertility and financial relief of households, and, finally, reconciliation of activity in various fields. Such initiatives improve the status of women both in the sphere of work and at home. The association of many EU internal markets will undoubtedly help to manage better those who take up employment (younger generation) or the so-called "unstable employment."

The problems of Europe are still associated with self-employed people, with family and migrant workers, with informal employment, with differentiated payment, with low protection of the employment status. They lower the level of social security and negatively affect social development. ${ }^{2}$

Table 7

Level of the minimum wage in the euro area per hour (in 2017)

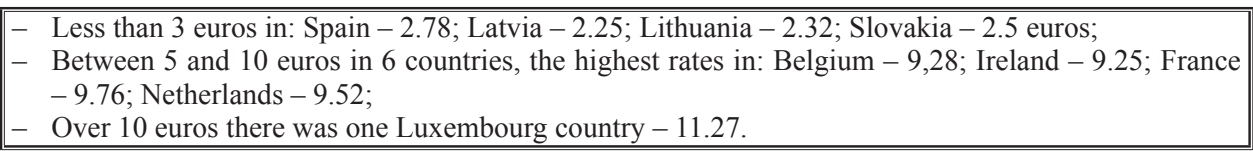

Source: Deutscher Bundestag, 19: 30.

${ }^{2}$ More on the challenges of social policy, especially the problems of women and the labor market, in countries at different stages of socio-economic development: World Employment Social Outlook. Trends for women 2018. Global snapshot. International Labor Office, Geneva, 2018, https://www.ilo. org/wcmsp5/groups/public/---dgreports/dcomm/---publ/documents/publication/wcms_619577.pdf. 
For some of the Central and Eastern European countries, the challenge is gender pay gap, ${ }^{3}$ minimum wage and a salary below the level of efficiency of national economies. We are also in the category of household income, the purchasing power of our money and the scale of poverty and social exclusion. In this regard, our image is spoiled by the South-East countries and they are, in particular, separated by a civilizational gap with the rich northern countries (Mischke, 2018: 413-439).

\section{$* * *$}

Social diversity on the European continent is a centuries-old historical fact. Political events, the logic of relations between states and economic and financial mechanisms have made them permanent. Different development pathways along with a cultural and religious factor have allowed to develop different models of social policy. In Europe, they are mainly of regional nature. Their individuality comes down to the essential aspects, ie to the construction of the model and the institutionalization of social policy, and in its framework to the relationship between the social sphere, the economic sphere and the institution of the state.

Real socio-social diversity can not be derived in a simple way from the multiplicity of social policy models. All the more so because quite separate social systems can create a comparable standard of living (eg Nord-West and Nord countries). Therefore, the causes of disparities that moved towards horizontal incoherence in Europe and within countries also in the vertical one, should be sought in the economy and in politics. The first factor determines GDP, and the second one - particularly important in Eastern and South-Eastern Europe - defines the nature of the political community, understanding and applying the principles and values of social policy (equality, solidarity, subsidiarity). Undoubtedly, Norden countries are implementing a higher standard in this regard, because political participation turns into economic and social, and civic rights are filled with social inclusion. The low quality of our policy is a regional limitation, there is no strategic continuity and a large variability of the government's teams. The attention is drawn to the lack of a sense of community and solidarity between (rich) elites and the rest of society. These values are certainly missing in relations within the EU, between the countries of the old and the new Union. An attempt to overcome these deficits is to create common internal markets. Meanwhile, governments and their economies not only compete with each other but also penetrate the European space to build further advantages. In such circumstances, it will be difficult to minimize multidimensional social diversity.

\section{REFERENCES}

Alber J. (2010), What the European and American welfare states have in common and where they differ: facts and fiction in comparisons of the European Social Model and the United States, "Journal of European Social Policy", Vol. 20, No. 2.

${ }^{3}$ Sweden: GE-Index in 2012: 74.2\%, G-Pay-Gap in 2014: 15,8\%; the employment rate for women $-77 \%$, men $-82 \%$; working mothers with children aged $0-6$ years $-76.6 \%$. Hungary: GE-Index in $2012-41.6 \%$; employment of women $55.9 \%$, men $67.8 \%$; part-time employment - women 8.7 , in total for women and men 6.4\%. L. Eigenmann, Y. Holl, E. Kovăts, J. Menge, K. Nink, A. Rosenplänter, A. Salles, 2016: 43, 59. 
Aust A., Leitner S., Lessenich S. (2002), Konjunktur und Krise des Europäischen Sozialmodells, "Politische Vierteljahresschrift", Heft 2.

Becker U. (2012), Die Sozialpolitik im Spannungsverhältnis von Nationalstaat und supranationalen Institutionen, "Sozialer Fortschritt", Heft 5.

Bericht zur Weltweiten Ungleiheit, Kurzfassung (2018), Deutsche Fassung, Text und Koordination Facundo Alvareda, Lucas Chancel, Thomas Piketty, Emmanuel Saez, Gabriel Zucman. Allgemeine coordination Lucas Chancel, World inequality Lab, 2017, Berlin.

Bericht zur Weltweiten Ungleiheit, Kurzfassung (2018), Deutsche Fassung, Text und Koordination Facundo Alvareda, Lucas Chancel, Thomas Piketty, Emmanuel Saez, Gabriel Zucman. Allgemeine coordination Lucas Chancel, World inequality Lab, 2018, Berlin.

Braunsdorf F. (2016), Fluchtursachen "Made in Europe" Über europäische Politik und ihren Zusammenhang mit Migraton und Flucht, Internationale Politikanalyse, Friederich Ebert Stiftung, Berlin.

Dauderstäd M., Keltek C. (2016), Kein Fortschritt beim Soziales Zusammenhalt in Europa, WISO 11/2016, Friedrich Ebert Stiftung, Bonn.

Deutscher Bundestag, 19. Wahlperiode, Drucksache 19/1210 14.03.2018, Antwort der Bundesregierung auf Kleine Anfrage der Abgeordneten Alexander Ulrich, Klaus Ernst, Jörg Cezanne, weiterer Abgeordneter und der Fraktion DIE LINKE, "Die wirtschaftliche Entwicklung in EU und Eurozone infolge der Eurokrisenpolitik."

Dufresne A. (2013), Hasło bojowe Unii Europejskiej - obniżać płace!, in: Koniec Europy jaka znamy, (ed.) P. Wielgosz, Instytut Wydawniczy Książka i Prasa, Warszawa.

Eigenmann L., Holl Y., Kovăts E., Menge J., Nink K., Rosenplänter A., Salles A. (2016), Auf dem Weg zur Geschlechtergerechtigkeit, Berichte aus Dänemark, Deutschland, Frankreich, Großbritannien, Österreich, Schweden, Schweiz, Ungar und USA. Internationale Politikanalyse, Friedrich Ebert Stiftung, Berlin.

Eigmüller M. (2012), Europäisierung der Sozialpolitik. Der Einfluß individueller Akteure auf dem Integrationsproze $\beta$, “Zeitschrift für Sozialreform,” Jg. 58, Heft 3.

Engler P., Klein M. (2017), Austertiätspolitik hat in Spanien, Portugal und Italien die krise verschärft, DIW Wochenblatt Nr. 8.

Engler P., Klein M. (2017), Austertiätspolitik hat in Spanien, Portugal und Italien die Krise verschärft, DIW Wochenblatt Nr. 8.

Eurostat (2016), Pressemitteilung 246/2016 - 8. Dezember 2016, Verdienststrukturerhebung. Jeder sechste Arbeitnehmenr in der Europäischen Uniono ist Niedriglohnempfänger. Große Unterschiede zwischen Mitgliedstaaten.

Finkenstädt V. (2017), Zugangshürden in der Gesundheitsversorgung. Ein europäischer Überblick, Wissenschaftliches Institut der PKV, Köln.

Gerhards J., Lengfeld H. (2013), Die Krise der Europäischen Union und die Herausforderungen an die Sozialintegration Europas, Verlag für Sozialwissenschaften, Wiesbaden.

Hermann Ch. (2013), Crisis, Structural Reform and the Dismantling of the European Social!Model(s), IPE Working Paper, No. 26.

Hermann Ch., Hinrichs K., Brosig M. (2012), Die Finanzkrise und ihre Auswirkungen auf Sozialstaaten und Arbeitsbeziehungen - ein europäischer Rundblick, FORBA, Wien.

Hermann Ch., Mahnkopf B. (2010), The Past and the Future of the European Social Model, Working Paper, Institute for International Political Economy, No. 5, Berlin.

Jepsen M., Serrano Pascual A. (2005), The European Social Model: an exercise in de construction, "Journal of European Social Policy," No. 15. 
Komisja Europejska - Komunikat prasowy (2017), Komisja przedstawia Biała Księgę w sprawie przyszłości Europy: Ścieżki do jedności dla UE 27, Bruksela, 1 marca 2017 r.

Komisja Europejska - Przemówienie. Przewodniczący Jean - Claude Juncker, Orędzie o stanie Unii 2017, Bruksela, 13 września 2017 r., https://ec.europa.eu/commission/presscorner/detail/p1/ SPEECH_17_3165 (22.04.2019).

Mapa dlugów, deficytów i nadwyżek w UE. Niemcy bardziej zadlużone od Polski, https://forsal.pl/ gospodarka/pkb/artykuly/1409367,zadluzenie-deficyt-w-panstwach-ue-polska-w-grupiesredniakow-dane-eurostatu.html (06.06.2019).

Mischke J. (2018), Deutschland in Europa, in: Datenreport 2018. Ein Sozialbericht für die Bundesrepublik Deutschland, Statistisches Bundesamt (Destatis), Wssenschaftszentrum Berlin fur Sozialforschung (WZB), Bonn.

Nachhaltiges Regieren in der OECD und EU (2016), Substainable Governance indicators 2016, Bertelsmann Stiftung, Gütersloh.

OECD (2019), Social Expenditure Database, www.oecd.org/social/expenditure.htm.

Pfetsch F. R. (2007), Das neue Europa, Verlag für Sozialwissenschaften, Wiesbaden.

Piepper M. (2018), Soziale Marktwirtschaft in der Europäischen Union. Das Modell für Europeas Zukunft im globalen Wettbewerb. Analysen und Argumente, Konrad Adenauer Stiftung, April 2018, Ausgabe 298, Sankt Augustin-Berlin.

Platzer H-W. (2011), Zur wissenschaftlichen Modelldebate und den Perspektiven der Europäischen Sozialpolitik unter der Vorzeichen der Weltwirtschafts-und Eurokrise und des EU-Reformvertrages, in: Europa? quo vadis, (ed.) G. Hentges, Verlag für Sozialwissenschaften, Wiesbaden.

Ribhegge H. (2011), Europäische Wirtschafts- und Sozialpolitik, Heidelberg.

Scheuer A. (2018), Lebensqualität in der Europäischen Union, in: Datenreport 2018. Ein Sozialbericht für die Bundesrepublik Deutschland, Statistisches Bundesamt (Destatis). Wssenschaftszentrum Berlin fur Sozialforschung (WZB), Bonn.

Schlussbericht (2017), Sozialgipfel zu den Themen faire Arbeitsplätze und Wachstum vom 17. Novemebr 2017 in Göteborg, Schweden.

Statistisches Jahrbuch Deutschland und Internationales 2018, wissen.nutzen, Statistisches Bundesamt (Destatis), https://www.destatis.de/DE/Themen/Querschnitt/Jahrbuch/statistisches-jahrbuch-2018-dl.pdf?_blob=publicationFile\&v=5.

Stuchlik A. (2008), Christian Kellermann, Europa auf dem Weg zur Sozialen Union? Die Sozialagenda der EU im Kontext europäischer Sozialstaatlichkeit. Internationale Politikanalyse, Friedrich Ebert Stiftung, Berlin.

Supiot A. (2013), Towards a European policy on work, in: N. Countouris, M. Freedland, Resocialising Europe in a time of crisis, Cambridge University Press, Cambridge-New York.

Szewior K. (2016), Bezpieczeństwo społeczne jednostki. Założenia i polska rzeczywistość, Oficyna Wydawnicza ASPRA-JR, Warszawa.

Szewior K. (2015), Kryzys społeczny w Europie w dobie przemian modelu i rzeczywistości, in: Kryzysy w procesie integracji europejskiej i sposoby ich przezwyciężania, (eds.) K. A. Wojtaszczyk, J. Nadolska, Warszawa.

Ubóstwo w Polsce w latach 2015 i 2016 (2017), (red. merytoryczna) A. Bieńkuńska, Urząd Statystyczny w Łodzi, Warszawa.

Witte L. (2004), Europäisches Sozialmodell und Sozialer Zusammenhalt: Welche Rolle spielt die EU?, "Europäische Politik”, Nr. 12.

World Emploument Social Outlook. Trends for women 2018. Global snapshot (2018), International Labour Office, Geneva, https://www.ilo.org/wcmsp5/groups/public/---dgreports/---dcomm/--publ/documents/publication/wcms_619577.pdf. 
Zatrudnienie $w$ sektorze publicznym pozostaje na niemal statym poziomie, https://stat.gov.pl/gospodarka-europejska/bloc-4d.html

Zukunft und Reform des Sozialstaats. Ergebnisse einer Umfrage in acht europäischen Ländern (2016), Auftraggeber: Vision Europe Summit, Germany, Gütersloh.

\begin{abstract}
The aim of the publication is to learn the dimensions of social differentiation by applying socioeconomic indicators, as well as to indicate the importance of economic and social conditions as the leading factors in building the social order of national states and the European Union. The main research question concerned the issue whether and under what conditions it is possible to achieve improvement in the level of social cohesion? The experience and knowledge allow to assume that the most important in achieving social and economic cohesion are: the level of economic development and socio-political consensus regarding the distribution and circulation of social goods, rather than the model of national social policy. The adopted assumption was verified, confirmed the dominant role of the social contract, the scope of social solidarism and the developed GDP. These elements determine social development and determine the competitive advantage of national economies. In view of the weakness of institutions and EU-wide solutions, they consolidate the multidimensional disproportions between European societies.

The analysis is based on research methods of politics and social policy. Statistical data was provided by national and EU institutions.
\end{abstract}

Keywords: social diversity, inequality, inconsistency, EU social model

\title{
WYMIARY ZRÓŻNICOWANIA SPOLECZNEGO EUROPY
}

\section{STRESZCZENIE}

Celem publikacji jest poznanie wymiarów społecznego zróżnicowania poprzez zastosowanie wskaźników społeczno-gospodarczych, a także wskazanie znaczenia uwarunkowań gospodarczych i społecznych jako wiodących czynników w budowaniu ładu społecznego państw narodowych oraz Unii Europejskiej. Zasadnicze pytanie badawcze dotyczyło kwestii czy i w jakich warunkach możliwe jest uzyskanie poprawy w poziomie spójności społecznej? Zebrane doświadczenie i wiedza pozwalają założyć, że istotniejsze w osiąganiu spójności społeczno-gospodarczej są: poziom rozwoju gospodarczego i konsensus społeczno-polityczny względem rozdziału i obiegu dóbr, niż model narodowej polityki społecznej. Przyjęte założenie zostało zweryfikowane, potwierdziło dominującą rolę umowy społecznej, zakresu solidaryzmu społecznego oraz wypracowanego PKB. Elementy te wyznaczają stan rozwoju społecznego oraz determinują przewagę konkurencyjną gospodarek narodowych. Wobec słabości instytucji i rozwiązań ogólnounijnych utrwalają wielowymiarowe dysproporcje między społeczeństwami europejskimi. Analiza bazuje na metodach badawczych nauki o polityce oraz polityki społecznej. Dane statystyczne dostarczyły instytucje krajowe i unijne.

Słowa kluczowe: społeczne zróżnicowanie, nierówność, niespójność, model społeczny UE 
